medRxiv preprint doi: https://doi.org/10.1101/2020.09.01.20185835; this version posted September 2, 2020. The copyright holder for this preprint (which was not certified by peer review) is the author/funder, who has granted medRxiv a license to display the preprint in perpetuity.

It is made available under a CC-BY-NC-ND 4.0 International license .

\title{
Circulating amino acids, amino acid metabolites, dipeptides, and other cationic metabolites and risk of breast cancer
}

Oana A. Zeleznik ${ }^{1 *}$, Raji Balasubramanian ${ }^{2 *}$, Yibai Zhao ${ }^{2}$, Lisa Frueh $^{1}$, Sarah Jeanfavre ${ }^{3}$, Julian AvilaPacheco $^{3}$, Clary B. Clish ${ }^{3}$, Shelley S. Tworoger ${ }^{4}$, A. Heather Eliassen ${ }^{1,5}$

${ }^{1}$ Channing Division of Network Medicine, Brigham and Women's Hospital and Harvard Medical School, Boston, MA, USA

${ }^{2}$ Department of Biostatistics \& Epidemiology, University of Massachusetts - Amherst, Amherst, MA, USA

${ }^{3}$ Broad Institute of Massachusetts Institute of Technology and Harvard, Cambridge, MA, USA

${ }^{4}$ Department of Cancer Epidemiology, Moffitt Cancer Center, Tampa, FL, USA

${ }^{5}$ Department of Epidemiology, Harvard T.H. Chan School of Public Health, Boston, MA, USA

*authors contributed equally to this work 
medRxiv preprint doi: https://doi.org/10.1101/2020.09.01.20185835; this version posted September 2, 2020. The copyright holder for this preprint (which was not certified by peer review) is the author/funder, who has granted medRxiv a license to display the preprint in perpetuity. It is made available under a CC-BY-NC-ND 4.0 International license .

\section{Abstract}

Background: Breast cancer is the most common malignancy among women in the United States, with more than 250,000 cases diagnosed each year. Metabolomics, which reflect the aggregate effects of genetics and the environment on an individual's metabolic state, can shed light on biochemical pathways involved in susceptibility to breast cancer. We investigated associations between pre-diagnostic circulating amino acidsrelated metabolites and subsequent risk of breast cancer among predominantly premenopausal women. Methods: In 1996-1999, 29,611 women (average age, 44 years) in the Nurses' Health Study II donated blood samples. Between blood collection and June 2011, 1057 women were diagnosed with breast cancer (average of 8 years after blood collection). Women were predominately premenopausal at the time of blood collection. 207 amino acid and amino acid-related metabolites were profiled with LC-MS/MS. Conditional logistic regression (CLR) was used to estimate odds ratios (ORs) of breast cancer and 95\% confidence intervals (CIs). Multivariable analyses evaluating the joint association of all metabolites with breast cancer risk were based on CLR with a lasso penalty (Lasso), CLR with an elastic net penalty (Elastic Net), and Random Forests. We used FDR to account for testing multiple hypotheses.

Results: Eleven metabolites were associated with breast cancer risk in CLR models, after adjustment for multiple comparisons ( $\mathrm{p}$ value $<0.05$ and $\mathrm{q}$ value $<0.20$; creatine had $\mathrm{q}$ value $>0.20$ ), 6 of which remained significant after adjustment for breast cancer risk factors (p-value <0.05). Higher levels of six metabolites, including 2-aminohippuric acid, DMGV, kynurenic acid, N2, N2-dimethylguanosine, phenylacetyl glutamine and piperine, were associated with lower breast cancer risk (e.g., piperine: $\mathrm{OR}_{\text {simple }}(95 \% \mathrm{CI})=0.85(0.78-0.93)$; $\left.\mathrm{OR}_{\text {adjusted }}(95 \% \mathrm{CI})=0.84(0.77-0.92)\right)$. Higher levels of asparagine, creatine and 3 lipids (C20:1 LPC, C34:3 PC plasmalogen, C40:7 PE plasmalogen) were associated with increased breast cancer risk (e.g., C40:7 PE plasmalogen $\left.\mathrm{OR}_{\text {simple }}(95 \% \mathrm{CI})=1.14(1.05-1.25) ; \mathrm{OR}_{\text {adjusted }}(95 \% \mathrm{CI})=1.11(1.01-1.22)\right)$. Piperine, 2 aminohippuric acid, C40:7 PE plasmalogen and creatine were also selected in multivariable modeling approaches (Lasso, Elastic Net, and Random Forests).

Conclusions: Two diet-related metabolites, piperine (responsible for the pungency of pepper) and 2aminohippuric acid (the glycine conjugate of the tryptophan metabolite anthranilic acid) were inversely 
medRxiv preprint doi: https://doi.org/10.1101/2020.09.01.20185835; this version posted September 2, 2020. The copyright holder for this preprint

(which was not certified by peer review) is the author/funder, who has granted medRxiv a license to display the preprint in perpetuity.

It is made available under a CC-BY-NC-ND 4.0 International license .

associated, while C40:7 PE plasmalogen (a highly unsaturated glycerophospholipid and key component of the lipid bilayer of cells) was positively associated with breast cancer risk among predominately premenopausal women, independent of established breast cancer risk factors. Further validation of the specific metabolite associations with breast cancer risk in independent cohorts is warranted. 
medRxiv preprint doi: https://doi.org/10.1101/2020.09.01.20185835; this version posted September 2, 2020. The copyright holder for this preprint (which was not certified by peer review) is the author/funder, who has granted medRxiv a license to display the preprint in perpetuity.

It is made available under a CC-BY-NC-ND 4.0 International license .

\section{Introduction}

Breast cancer is the most common malignancy among women in the United States, with more than 250,000 cases diagnosed each year ${ }^{1}$. Known modifiable risk factors are estimated to account for only around one-third of postmenopausal breast cancers $^{2-4}$, and an even smaller fraction of premenopausal cancers ${ }^{2,5}$. Thus, new strategies are needed for the identification of modifiable risk factors, especially for premenopausal breast cancers.

Metabolites are small molecules that are produced and consumed by cellular metabolism. The study of the complete collection of metabolites, called metabolomics, provides a direct signature of cellular activity in the body and has emerged as a powerful tool for the diagnosis, characterization, and prediction of disease. Metabolomic methods have uncovered biomarkers for a wide variety of cancers including colorectal, gastric, pancreatic, liver, ovarian, breast, urinary, esophageal and lung ${ }^{6}$. In breast cancer, metabolomics has proven useful for tumor biology characterization, predicting treatment response, anticipating recurrence, and estimating prognosis ${ }^{7}$.

More recently, prospective epidemiological studies have used metabolomics to identify metabolite risk

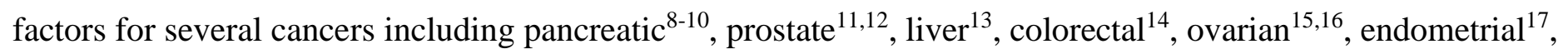
and breast cancer ${ }^{18-22}$. For breast cancer, studies have used both targeted ${ }^{18,21,23}$ and untargeted ${ }^{20,22}$ methods to $^{2}$ discover metabolomic risk factors associated with $\operatorname{diet}^{20,23}, \mathrm{BMI}^{21}$, microbiota metabolism ${ }^{20}$, lipid, amino acid, and other metabolic pathways ${ }^{18,20,22}$. While several studies stratified results by estrogen receptor (ER) status $^{18,21,23}$, no prospective metabolomic breast cancer studies have investigated differential effects by menopausal status.

In this study, we assessed the association of over 200 prospectively measured circulating amino acid and amino acid-related metabolites with risk of breast cancer among the predominantly premenopausal women (1057 cases and 1057 matched controls) of the Nurses’ Health Study II (NHSII). 
medRxiv preprint doi: https://doi.org/10.1101/2020.09.01.20185835; this version posted September 2, 2020. The copyright holder for this preprint (which was not certified by peer review) is the author/funder, who has granted medRxiv a license to display the preprint in perpetuity.

It is made available under a CC-BY-NC-ND 4.0 International license .

\section{Methods}

\section{$\underline{\text { Study Population }}$}

In 1989, 116,429 female registered nurses aged 25-42y returned a mailed questionnaire and were enrolled in the NHSII. Participants have been followed biennially since 1989 with questionnaires collecting information on reproductive history, lifestyle factors, diet, medication use, and new disease diagnoses.

In 1996-1999, 29,611 NHSII participants aged 32-54y contributed blood samples, as previously described $^{24}$. Of these, 18,521 women who had not used oral contraceptives, been pregnant or breastfed in the previous six months provided samples timed within the menstrual cycle, targeting the early follicular (days 3 to 5 of the cycle) and mid-luteal (7 to 9 days prior to expected start of next cycle) phases. The remaining women donated a single untimed sample. Follicular plasma was separated and frozen by the participants and returned with the luteal sample; samples were collected and shipped overnight to our laboratory where we processed and archived aliquots of white blood cell, red blood cell, and plasma in liquid nitrogen freezers $\left(\leq-130^{\circ} \mathrm{C}\right)$. Followup in the blood subcohort is high (96\% in 2011).

The study protocol was approved by the institutional review boards of the Brigham and Women's Hospital and Harvard T.H. Chan School of Public Health, and those of participating registries as required. The return of the self-administered questionnaire and blood sample was considered to imply consent.

\section{$\underline{\text { Case and Control Selection }}$}

Cases of breast cancer were identified after blood collection among women who had no reported cancer (other than nonmelanoma skin). 1057 cases (invasive cases $n=780$ ) were diagnosed between 1999 and 2011. Breast cancer cases were reported by the participant, which were confirmed by medical record reviews $(n=1015)$ or verbally by the nurse $(n=42)$. Given the high confirmation rate by medical record for breast cancer in this cohort (99\%), all cases are included in this analysis.

One control was matched per case by the following factors: age (+/- 2y), menopausal status and postmenopausal hormone therapy (HT) use at blood collection and diagnosis (premenopausal, postmenopausal 
medRxiv preprint doi: https://doi.org/10.1101/2020.09.01.20185835; this version posted September 2, 2020. The copyright holder for this preprint (which was not certified by peer review) is the author/funder, who has granted medRxiv a license to display the preprint in perpetuity.

It is made available under a CC-BY-NC-ND 4.0 International license .

and not taking HT, postmenopausal and taking HT, and unknown), and month (+/- 1mo), time of day (+/- 2h), fasting status at blood collection ( $<8 \mathrm{~h}$ after a meal or unknown; $>10 \mathrm{~h}$ ), race/ethnicity (African-American, Asian, Hispanic, Caucasian, other) and luteal day (+/- 1d; timed samples only).

\section{$\underline{\text { Covariate Information }}$}

Data on breast cancer risk factors, including anthropometric measures, reproductive history, and lifestyle factors, were collected from questionnaires administered biennially and at the time of blood collections. Case characteristics, including invasive vs. in situ, histologic grade, estrogen and progesterone receptor (ER, PR), were extracted from pathology reports. As previously described ${ }^{25}$, immunohistochemical results for ER and PR, read manually by a study pathologist, were included for cases with available tumor tissue included in tissue microarrays.

\section{$\underline{\text { Laboratory Assay }}$}

Plasma metabolites were profiled at the Broad Institute of MIT and Harvard (Cambridge, MA) using a liquid chromatography tandem mass spectrometry (LC-MS) method designed to measure polar metabolites such as amino acids, amino acids derivatives, dipeptides, and other cationic metabolites as described previously ${ }^{26-29}$. Pooled plasma reference samples were included every 20 samples and results were standardized using the ratio of the value of the sample to the value of the nearest pooled reference multiplied by the median of all reference values for the metabolite. Samples were run together, with matched case-control pairs (as sets) distributed randomly within the batch, and the order of the case and controls within each pair randomly assigned.

Therefore, the case and its control were always directly adjacent to each other in the analytic run, thereby limiting variability in platform performance across matched case-control pairs. In addition, 238 quality control (QC) samples, to which the laboratory was blinded, were also profiled. These were randomly distributed among the participants' samples.

Hydrophilic interaction liquid chromatography (HILIC) analyses of water soluble metabolites in the positive ionization mode were conducted using an LC-MS system comprised of a Shimadzu Nexera X2 U-HPLC (Shimadzu Corp.; Marlborough, MA) coupled to a Q Exactive mass spectrometer (Thermo Fisher Scientific; Waltham, MA). Metabolites were extracted from plasma (10 $\mu \mathrm{L})$ using $90 \mu \mathrm{L}$ of acetonitrile/methanol/formic 
medRxiv preprint doi: https://doi.org/10.1101/2020.09.01.20185835; this version posted September 2, 2020. The copyright holder for this preprint (which was not certified by peer review) is the author/funder, who has granted medRxiv a license to display the preprint in perpetuity.

It is made available under a CC-BY-NC-ND 4.0 International license .

acid (74.9:24.9:0.2 v/v/v) containing stable isotope-labeled internal standards (valine-d8, Sigma-Aldrich; St.

Louis, MO; and phenylalanine-d8, Cambridge Isotope Laboratories; Andover, MA). The samples were centrifuged $\left(10 \mathrm{~min}, 9,000 \mathrm{x} \mathrm{g}, 4^{\circ} \mathrm{C}\right)$, and the supernatants were injected directly onto a $150 \times 2 \mathrm{~mm}, 3 \mu \mathrm{m}$

Atlantis HILIC column (Waters; Milford, MA). The column was eluted isocratically at a flow rate of 250 $\mu \mathrm{L} / \mathrm{min}$ with $5 \%$ mobile phase $\mathrm{A}$ (10 $\mathrm{mM}$ ammonium formate and $0.1 \%$ formic acid in water) for 0.5 minute followed by a linear gradient to $40 \%$ mobile phase B (acetonitrile with $0.1 \%$ formic acid) over 10 minutes. MS analyses were carried out using electrospray ionization in the positive ion mode using full scan analysis over 70-800 m/z at 70,000 resolution and $3 \mathrm{~Hz}$ data acquisition rate. Other MS settings were: sheath gas 40, sweep gas 2 , spray voltage $3.5 \mathrm{kV}$, capillary temperature $350^{\circ} \mathrm{C}$, S-lens $\mathrm{RF} 40$, heater temperature $300^{\circ} \mathrm{C}$, microscans 1, automatic gain control target 1e6, and maximum ion time $250 \mathrm{~ms}$. Metabolite identities were confirmed using authentic reference standards or reference samples.

In total, 259 known metabolites were measured in this study. Metabolites not passing our previously conducted processing delay pilot study ${ }^{29}$ were excluded from this analysis $(\mathrm{N}=33)$. All metabolites $(\mathrm{N}=226)$ included here exhibited good reproducibility within person over 1-2 years ${ }^{29} .206$ metabolites had no missing values among participant samples. One metabolite had $<10 \%$ missing values and 19 metabolites had $\geq 10 \%$ missing values. Most of the metabolites $(\mathrm{N}=191)$ had a coefficient of variation $(\mathrm{CV})<25 \%$ and an intraclass correlation coefficient (ICC) $>0.4$ among blinded QC samples. Twenty-five metabolites had CV $\geq 25 \%$, five had ICCs $\leq 0.4$, and five metabolites had $\mathrm{CV} \geq 25 \%$ and $\mathrm{ICC} \leq 0.4$.

\section{$\underline{\text { Statistical Analysis }}$}

Metabolite levels were natural logarithm transformed and standardized prior to statistical analysis. Missing values were imputed by one half the lowest observed value per metabolite, for metabolites with $<10 \%$ missing values $(\mathrm{N}=1)$. Metabolites with $>10 \%$ missing values $(\mathrm{N}=19)$ were excluded from the main analysis and evaluated in an exploratory analysis. 
medRxiv preprint doi: https://doi.org/10.1101/2020.09.01.20185835; this version posted September 2, 2020. The copyright holder for this preprint (which was not certified by peer review) is the author/funder, who has granted medRxiv a license to display the preprint in perpetuity.

It is made available under a CC-BY-NC-ND 4.0 International license .

Association of metabolite levels with breast cancer risk was assessed in metabolite-by-metabolite models and in multivariable analyses that included all metabolites simultaneously.

The association of individual metabolites with breast cancer risk was assessed in conditional logistic regression models. In a simple model, each metabolite was included without adjustment for other factors. In an adjusted model, the following additional factors were included: BMI at age 18, weight change from age 18 to time of blood draw, age at menarche, parity and age at first birth, family history of breast cancer, diagnosis of benign breast disease, physical activity, alcohol consumption, exogenous hormone use and breastfeeding history. Odds ratios $(\mathrm{OR})$ and $95 \%$ confidence intervals $(95 \% \mathrm{CI})$ were estimated for a one-unit (one standard deviation) increase in the log-transformed and standardized metabolites levels.

We performed analyses restricting to premenopausal women at blood collection, and analyses stratified by BMI ( $<25$ vs. $\left.\geq 25 \mathrm{~kg} / \mathrm{m}^{2}\right)$ and ER status. In a sensitivity analysis, we observed similar results between conditional logistic regression and unconditional logistic regression adjusting for the matching factors. Thus, stratified analyses were conducted using unconditional logistic regression, additionally adjusting for the matching factors. To test for effect modifications by BMI and ER status, we included cross-product terms in conditional logistic models and report the p-value for that interaction. As ER status represents a case characteristic, we assigned each control the ER status of its matched case.

In an exploratory analysis we assessed the association with risk of breast cancer for the 19 metabolites with $>10 \%$ missing values. We included the continuous metabolite level as well as a presence/absence indicator in the fully adjusted conditional logistic regression model and performed a likelihood-ratio test (full model compared to a model excluding both the metabolite and the presence/absence indicator) to estimate the significance level of the association. 
medRxiv preprint doi: https://doi.org/10.1101/2020.09.01.20185835; this version posted September 2, 2020. The copyright holder for this preprint (which was not certified by peer review) is the author/funder, who has granted medRxiv a license to display the preprint in perpetuity.

It is made available under a CC-BY-NC-ND 4.0 International license .

Multivariable analyses evaluating the joint association of the 207 metabolites with breast cancer risk were based on (1) conditional logistic regression with lasso penalty ('Lasso'), (2) conditional logistic regression with an elastic net penalty ('Elastic Net'), and (3) Random Forests. In the Lasso and Elastic Net analyses, a minimally adjusted model included only the set of 207 metabolites, whereas a fully adjusted model further adjusted for the risk factors noted above. In each analysis, the optimal values of the regularization parameter(s) were estimated as that which minimizes the average deviance in the left-out partitions, in a 10-fold cross validation procedure. A p-value for each metabolite was obtained from a permutation test in which the case/control labels were permuted within each matched stratum. A p-value for each metabolite was calculated as the proportion of permutations (out of 250) in which the magnitude of the coefficient under label permutation was at least as large as the regression coefficient in the observed dataset. Analyses were carried out using the R library clogitL1 ${ }^{30}$.

Random Forests analyses included a minimally adjusted model that included the 207 metabolites and matching factors. A fully adjusted model also included the additional risk factors noted above. In all analyses, the parameter mtry corresponding to the number of variables randomly sampled as candidates at each split was set to the square root of the total number of covariates in the model. Each classifier was an aggregate of 5000 trees. A p-value for each metabolite was obtained from a permutation test as described above in which the case/control labels were randomly permuted 100 times. Analyses were carried out using the R library randomForest ${ }^{31}$.

To adjust for multiple testing in the conditional logistic regression and the multivariable models we estimated the positive FDR based on the q-value procedure ${ }^{32}$. Metabolites that satisfied a p-value less than 0.05 and corresponding q-value less than 0.20 in the minimally adjusted model were discussed as primary findings.

Criterion for statistical significance: Metabolites that met a p-value $<0.05$ and q-value $<0.20$ in at least one of the four models (Conditional Logistic Regression, Lasso, Elastic Net and Random Forests) with minimal adjustment were considered as statistically significant. An exception was made for metabolites that did not meet 
medRxiv preprint doi: https://doi.org/10.1101/2020.09.01.20185835; this version posted September 2, 2020. The copyright holder for this preprint

(which was not certified by peer review) is the author/funder, who has granted medRxiv a license to display the preprint in perpetuity.

It is made available under a CC-BY-NC-ND 4.0 International license .

a p-value threshold $<0.05$ in the conditional logistic regression: 4 metabolites that met the threshold for

statistical significance in Lasso only but had high raw p-values $(>0.3)$ in the conditional logistic regression were excluded (C12:1 carnitine, C22:5 LPC, C46:2 TAG, glycine).

A metabolite score was estimated for each participant as a linear combination of all metabolites that met the threshold for statistical significance. The coefficients associated with each metabolite were estimated in a conditional logistic regression model with the Lasso penalty that included all metabolites simultaneously and with full adjustment for all potential confounders. 
medRxiv preprint doi: https://doi.org/10.1101/2020.09.01.20185835; this version posted September 2, 2020. The copyright holder for this preprint (which was not certified by peer review) is the author/funder, who has granted medRxiv a license to display the preprint in perpetuity.

\section{It is made available under a CC-BY-NC-ND 4.0 International license .}

\section{Results}

$\underline{\text { Study population }}$

1057 cases and 1057 matched controls were included in this study (Table 1). Women were an average 53 years old and predominantly premenopausal $(80 \%)$ at the time of blood collection. At diagnosis, $42 \%$ of the women were premenopausal and $46 \%$ were postmenopausal.

Table 1: Characteristics of breast cancer cases and matched controls at blood collection in the Nurses' Health Study II, mean (SD) or \%.

\begin{tabular}{|c|c|c|}
\hline & $\begin{array}{l}\text { Cases } \\
(n=1057)\end{array}$ & $\begin{array}{l}\text { Controls } \\
(n=1057)\end{array}$ \\
\hline Age at blood collection^, $\mathbf{y}$ & $44.7(4.5)$ & $44.8(4.4)$ \\
\hline Age at menarche, $y$ & $12.4(1.3)$ & $12.8(1.4)$ \\
\hline \multicolumn{3}{|l|}{ Parity and age at first birth, \%: } \\
\hline Nulliparous & 21.1 & 15.9 \\
\hline $1-2$ children, $\geq 25 y$ & 39.2 & 34.9 \\
\hline 1-2 children, $<25 y$ & 14.7 & 15.9 \\
\hline $3+$ children, $<25 y$ & 11.3 & 16.6 \\
\hline $3+$ children, $\geq 25 y$ & 13.8 & 14.2 \\
\hline Ever breastfed, \%: & 63.1 & 65.0 \\
\hline Family history of breast cancer, \%: & 17.4 & 10.8 \\
\hline Personal history of benign breast disease, \%: & 22.1 & 15.6 \\
\hline BMI at age $18, \mathrm{~kg} / \mathrm{m}^{2}$ & $20.8(2.9)$ & $21.1(3.1)$ \\
\hline Weight change between age 18 and blood collection, $\mathrm{kg}$ & $11.6(12.0)$ & $12.6(13.2)$ \\
\hline Physical activity, MET-hrs/wk & $18.0(15.3)$ & $18.1(15.5)$ \\
\hline Alcohol consumption, g/day & $3.8(6.9)$ & $3.3(5.6)$ \\
\hline Past/current exogenous hormone use*, \%: & 86.3 & 86.7 \\
\hline \multicolumn{3}{|l|}{ Menopausal status at blood collection^^,\%: } \\
\hline Premenopausal & 80.2 & 79.7 \\
\hline Postmenopausal & 12.7 & 13.1 \\
\hline Unknown & 7.1 & 7.3 \\
\hline \multicolumn{3}{|l|}{ Menopausal status at $\operatorname{diagnosis}^{\wedge}, \%$ : } \\
\hline Premenopausal & 42.0 & 42.2 \\
\hline Postmenopausal & 46.4 & 47.1 \\
\hline Unknown & 11.6 & 10.7 \\
\hline Caucasian^$^{\wedge}, \%:$ & 97.2 & 98.4 \\
\hline Fasting $(>8 \mathrm{~h})$ at blood collection^, \% & 68.7 & 74.7 \\
\hline
\end{tabular}

* oral contraceptive or menopausal hormone therapy

$\wedge$ matching factor 
medRxiv preprint doi: https://doi.org/10.1101/2020.09.01.20185835; this version posted September 2, 2020. The copyright holder for this preprint (which was not certified by peer review) is the author/funder, who has granted medRxiv a license to display the preprint in perpetuity. It is made available under a CC-BY-NC-ND 4.0 International license .

\section{$\underline{\text { Conditional logistic regression (CLR) }}$}

Eleven metabolites were significantly associated with risk of breast cancer based on the simple model

(Figure 1, Supplementary Table 1). Six metabolites were associated with lower risk while five metabolites were associated with higher risk of overall breast cancer. Dimethylguanidino valeric acid (DMGV; OR per 1-SD increase $(95 \% \mathrm{CI})=0.84(0.77-0.92)), 2$-aminohippuric acid $(\mathrm{OR}(95 \% \mathrm{CI})=0.84(0.76-0.92))$ and piperine $(\mathrm{OR}$ $(95 \% \mathrm{CI})=0.85(0.78-0.93))$ had the strongest inverse associations. C40:7 phosphatidylethanolamine (PE) plasmalogen $(\mathrm{OR}(95 \% \mathrm{CI})=1.14(1.05-1.25))$ and asparagine $(\mathrm{OR}(95 \% \mathrm{CI})=1.14(1.04-1.26))$ had the strongest positive associations. Creatine was the only metabolite with q-value $>0.2$ in the simple model but is included here as q-value $<0.2$ in both Lasso models. Results were similar when we included adjustment for breast cancer risk factors (DMGV: 0.88 (0.79-0.97); 2-aminohippuric acid: 0.85 (0.77-0.93); C40:7 PE: plasmalogen: 1.11 $(1.01=1.22)$; asparagine: $1.10(1.00-1.22))$ and when we restricted to premenopausal women (Figure 1, Supplementary Table 2) or ER+ tumors (Figure 1, Supplementary Table 3).

Among the 11 selected metabolites, only DMGV showed effect modification by BMI with stronger associations among women with high BMI (adjusted model, high BMI: OR (95\%CI)=0.82 (0.70-0.97); normal BMI: OR $(95 \% \mathrm{CI})=0.94(0.83-1.06) ; \mathrm{p}$-interaction=0.04). Significant interactions with BMI were observed for several additional metabolites that were not significant overall; for example C36:4 DAG/TAG fragment (high BMI: OR $(95 \% \mathrm{CI})=0.92(0.80-1.06)$; normal BMI: OR $(95 \% \mathrm{CI})=1.21(1.06-1.37)$; p-interaction=0.005), serine (high BMI: OR $(95 \% \mathrm{CI})=1.19(1.04-1.38)$; normal BMI: OR $(95 \% \mathrm{CI})=0.93(0.83-1.05)$; p-interaction=0.008), and proline betaine (high BMI: OR $(95 \% \mathrm{CI})=0.82(0.72-0.94)$; normal BMI: OR $(95 \% \mathrm{CI})=1.04(0.92-1.17)$; pinteraction $=0.017)$.

Of the 11 selected metabolites, we only observed stronger associations with risk of ER- tumors in the adjusted model (ER-; Supplementary Table 3) for asparagine (ER- tumors: OR (95\%CI)=1.21 (0.99-1.47); ER+ tumors: OR $(95 \% \mathrm{CI})=1.06(0.94-1.18)$; p-interaction=0.03). Three additional metabolites were suggestively different by ER status: betaine $($ ER- tumors: OR $(95 \% \mathrm{CI})=0.89(0.73-1.09)$; ER+ tumors: OR $(95 \% \mathrm{CI})=1.07(0.96-1.20)$; p- 
medRxiv preprint doi: https://doi.org/10.1101/2020.09.01.20185835; this version posted September 2, 2020. The copyright holder for this preprint (which was not certified by peer review) is the author/funder, who has granted medRxiv a license to display the preprint in perpetuity. It is made available under a CC-BY-NC-ND 4.0 International license .

interaction=0.02), 4-acetamidobutanate $(\mathrm{ER}-$ tumors: OR $(95 \% \mathrm{CI})=0.89(0.72-1.09)$; ER+ tumors: OR

$(95 \% \mathrm{CI})=0.97(0.87-1.08) ;$ p-interaction=0.03), and histidine $(\mathrm{ER}-$ tumors: OR $(95 \% \mathrm{CI})=1.06(0.87-1.29) ; \mathrm{ER}+$

tumors: OR $(95 \% \mathrm{CI})=1.01(0.91-1.13)$; p-interaction=0.05).

Figure 1: Odds ratios and 95\% confidence intervals (CI) per 1 SD increase for metabolites significantly associated with risk of overall breast cancer ( $\mathrm{p}$-value $<0.05$ and q-value $<0.2$ ) in Nurses' Health Study II, among premenopausal women only, by BMI category $(<25, \geq 25)^{* * *}$, and by ER status (ER positive, ER negative)****. Creatine, although not selected by the conditional logistic regression (p-value $<0.05$, qvalue $>0.2$ ), is shown here for completeness, as is was selected by the multivariable models.
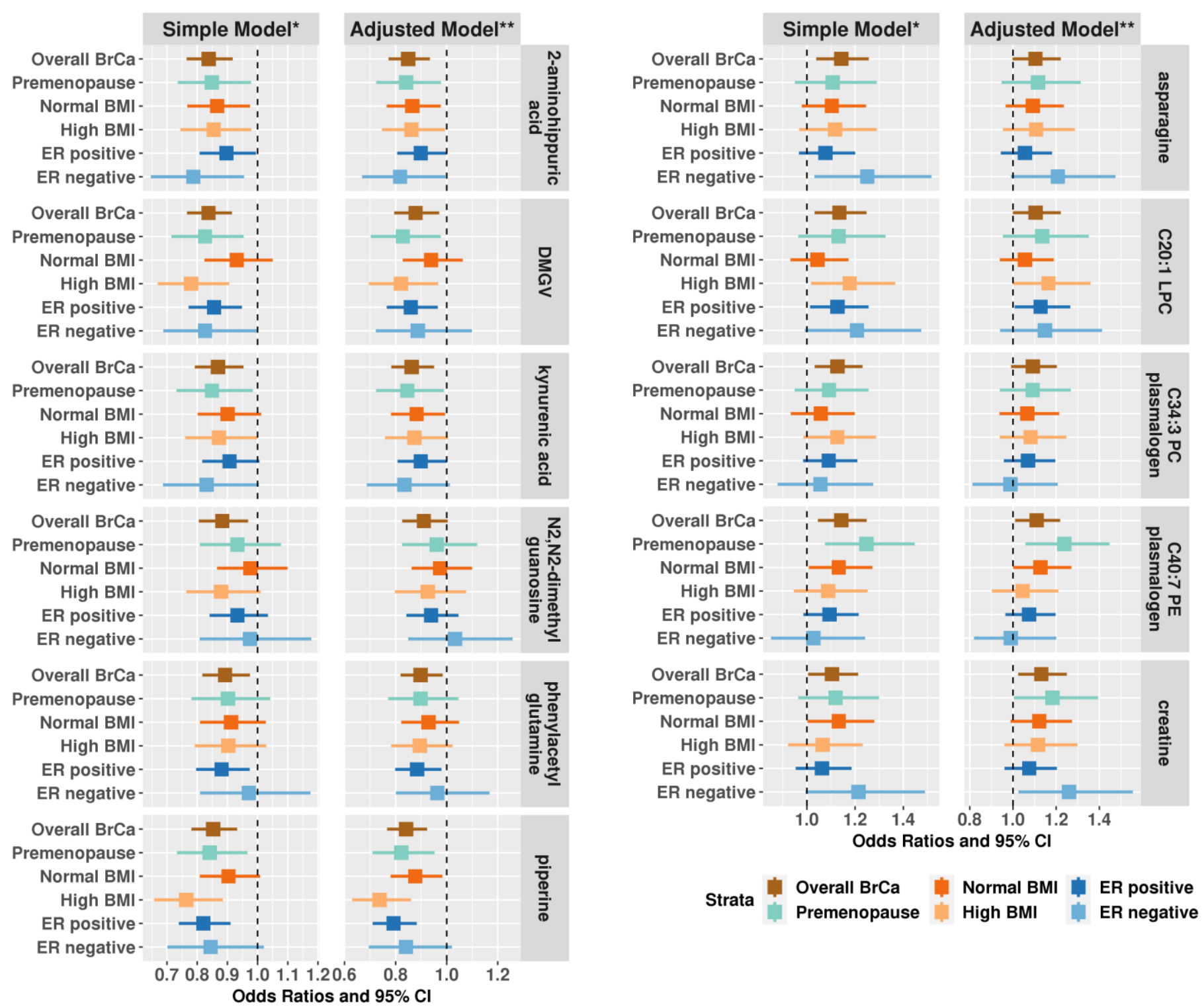

Strata

Overall BrCa

Premenopause

Normal BMI ER positive

High BMI

ER negative

\footnotetext{
*: Simple model: adjusts for matching factors including menopause status at blood draw, time of blood draw, date/season of blood draw, luteal day at blood draw, fasting status at blood draw, menopausal status at diagnosis and race.

** Adjusted model: in addition to matching factors, this model adjusts for BMI at age 18, weight change between age 18 and time of blood draw, age at menarche, parity and age at first birth, family history of breast cancer, personal history of benign breast disease, physical activity, alcohol consumption, exogenous hormone use, breast feeding history.

*** All p-heterogeneity by BMI category were $>0.07$ except for DMGV p-heterogeneity $=0.04$ (simple and adjusted model).

$* * * *$ All p-heterogeneity by ER status were $>0.13$ except for asparagine $\mathrm{p}$-heterogeneity $=0.02 / 0.03$ (simple/adjusted model).
} 
medRxiv preprint doi: https://doi.org/10.1101/2020.09.01.20185835; this version posted September 2, 2020. The copyright holder for this preprint (which was not certified by peer review) is the author/funder, who has granted medRxiv a license to display the preprint in perpetuity.

It is made available under a CC-BY-NC-ND 4.0 International license .

In an exploratory analysis including metabolites with $>10 \%$ missing values $(\mathrm{N}=19 ; 4$ metabolites had $>90 \%$ missingness), metoprolol (45\% missing values) was nominally significantly associated with risk of breast cancer (likelihood-ratio test p-value=0.04; data not shown). Women with detectable metoprolol levels had a $23 \%$ higher risk (presence-absence indicator $\mathrm{p}$-value=0.07) of breast cancer compared to women with undetectable metoprolol. However, among women with measured metoprolol, higher levels were associated with lower risk (OR per one unit increase in log-transformed and standardized metabolite levels $=0.91$, pvalue $=0.14)$. The remaining metabolites with high missingness were not associated with risk of breast cancer.

\section{Multivariable models of the joint association of all metabolites}

The inverse association of piperine with risk of breast cancer met the threshold for statistical significance (pvalue $<0.05$ and q-value $<0.20$ ) in all three simple (without adjustment for risk factors) multivariable models, Lasso, Elastic Net and Random Forests (Tables 2 and 3). In addition, DMGV and N2,N2-dimethylguanosine were detected in the Random Forests model with minimal adjustment, satisfying a q-value threshold of 0.05. Higher levels of C40:7 PE plasmalogen and creatine were associated with increased breast cancer risk in CLR Lasso models (q-value<0.20). These associations remained significant after further adjustment for risk factors (nominal $\mathrm{p}<0.05$ ) with the exception of N2,N2-dimethylguanosine in Random Forests ( $\mathrm{p}=0.05)$ and piperine in Elastic Net (nominal p-value<0.05, q-value $>0.2$ ).

When all eleven identified metabolites were assessed together in an adjusted lasso CLR model, ten metabolites remained independently associated with risk of breast cancer. The direction of association in the lasso CLR model was consistent with the previous CLR and multivariable models except for N2,N2-dimethylguanosine who's coefficient was estimated to be equal to zero, reflecting its high correlation with kynurenic acid and 2aminohippuric acid (Figure 2). 
medRxiv preprint doi: https://doi.org/10.1101/2020.09.01.20185835; this version posted September 2, 2020. The copyright holder for this preprint (which was not certified by peer review) is the author/funder, who has granted medRxiv a license to display the preprint in perpetuity.

It is made available under a CC-BY-NC-ND 4.0 International license .

Table 2: All metabolites that met $q-v a l u e<0.2$ in at least 1 primary model analysis that adjusts for matching factors.

\begin{tabular}{|c|c|c|c|c|c|c|c|c|c|}
\hline \multirow[b]{2}{*}{ Metabolites } & \multicolumn{4}{|c|}{ Simple model ${ }^{\star *}$} & \multirow{2}{*}{$\begin{array}{c}\text { Number } \\
\text { of } \sqrt{ }\end{array}$} & \multicolumn{4}{|c|}{ Adjusted model ${ }^{\star * \star}$} \\
\hline & $\underset{\text { tic }}{\text { Logis }}$ & $\begin{array}{l}\text { Las } \\
\text { so }\end{array}$ & $\begin{array}{c}\text { Elastic } \\
\text { Net }\end{array}$ & $\begin{array}{l}\text { Random } \\
\text { Forest }\end{array}$ & & $\begin{array}{c}\text { Logis } \\
\text { tic }\end{array}$ & $\begin{array}{l}\text { Las } \\
\text { so }\end{array}$ & $\begin{array}{c}\text { Elastic } \\
\text { Net }\end{array}$ & $\begin{array}{c}\text { Random } \\
\text { Forest }\end{array}$ \\
\hline DMGV & $\sqrt{ } *$ & * & & $\sqrt{*}$ & 2 & * & & & $\sqrt{*}$ \\
\hline $\begin{array}{l}\text { 2-aminohippuric } \\
\text { acid }\end{array}$ & $\sqrt{*}$ & & & * & 1 & $\sqrt{ }^{*}$ & & & * \\
\hline piperine & $\sqrt{*}$ & $\sqrt{*}$ & $\sqrt{*}$ & $\sqrt{ }^{*}$ & 4 & $\sqrt{ }^{*}$ & $\sqrt{*}$ & * & $\sqrt{ }^{*}$ \\
\hline kynurenic acid & $\sqrt{ }^{*}$ & * & & & 1 & $\sqrt{ } *$ & $\sqrt{*}$ & & \\
\hline $\begin{array}{c}\mathrm{N} 2, \mathrm{~N} 2- \\
\text { dimethylguanosine }\end{array}$ & $\sqrt{*}$ & & & $\sqrt{ }^{*}$ & 2 & & & & \\
\hline $\begin{array}{l}\text { Phenylacetyl- } \\
\text { glutamine }\end{array}$ & $\sqrt{*}$ & * & & & 1 & * & $\sqrt{ } *$ & & \\
\hline $\begin{array}{c}\text { C34:3 PC } \\
\text { plasmalogen }\end{array}$ & $\sqrt{ } *$ & * & & * & 1 & & $\sqrt{*}$ & & $\sqrt{ }^{*}$ \\
\hline C20:1 LPC & $\sqrt{*}$ & & & & 1 & & & & \\
\hline $\begin{array}{c}\text { C40:7 PE } \\
\text { plasmalogen }\end{array}$ & $\sqrt{ }^{*}$ & $\sqrt{*}$ & & * & 2 & * & $\sqrt{*}$ & & * \\
\hline asparagine & $\sqrt{*}$ & * & * & * & 1 & & * & & * \\
\hline creatine & * & $\sqrt{*}$ & * & & 1 & * & $\sqrt{*}$ & & \\
\hline
\end{tabular}

\section{$\sqrt{\text { q-value }}<0.2$}

* if p-value < 0.05;4 metabolites that met threshold for statistical significance in Lasso only but had Logistic regression raw p values > 0.3 were excluded (C12:1 carnitine, C22:5 LPC, C46:2 TAG, glycine).

**: Simple model: adjusts for matching factors including menopause status at blood draw, time of blood draw, date/season of blood draw, luteal day at blood draw, fasting status at blood draw, menopausal status at diagnosis and race.

*** Adjusted model: in addition to matching factors, this model adjusts for BMI at age 18, weight change between age 18 and time of blood draw, age at menarche, parity and age at first birth, family history of breast cancer, personal history of benign breast disease, physical activity, alcohol consumption, exogenous hormone use, breast feeding history.

Figure 2: Heatmap of all pairwise correlations among the 11 metabolites associated with breast cancer risk. Positive correlations are shown in shades of red while inverse correlations are shown in shades of blue.

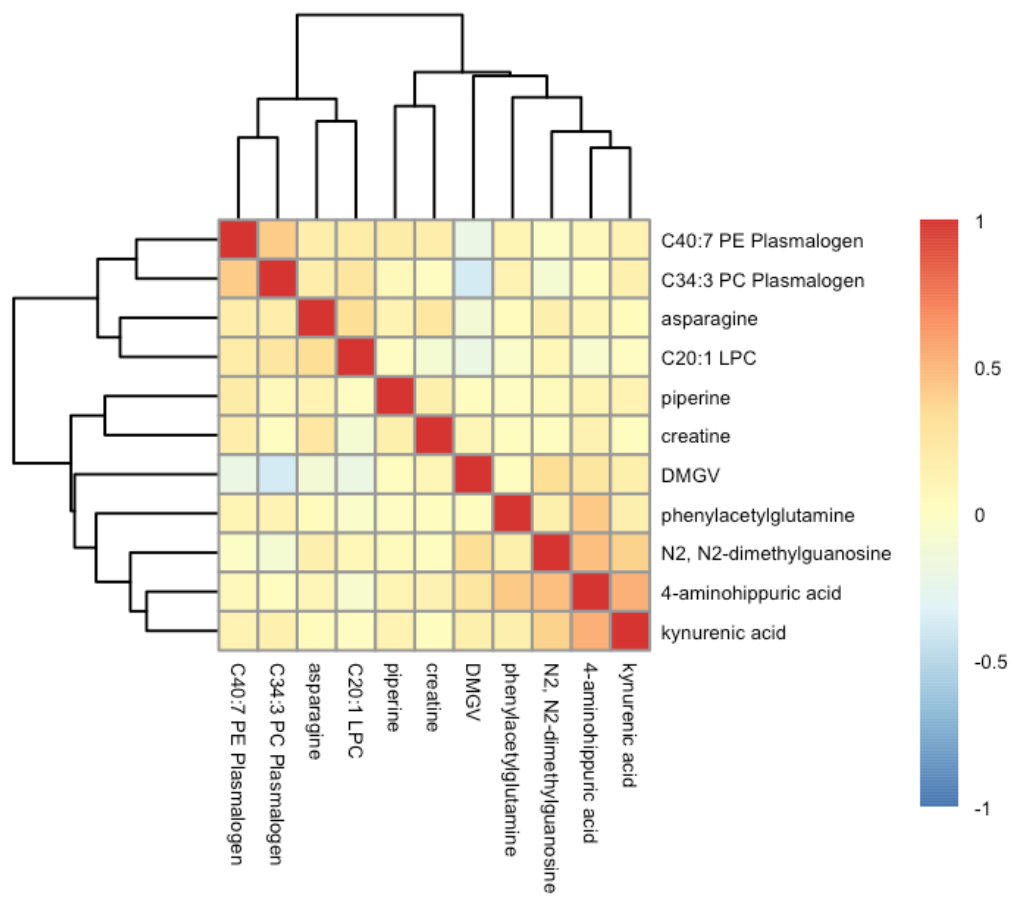


medRxiv preprint doi: https://doi.org/10.1101/2020.09.01.20185835; this version posted September 2, 2020. The copyright holder for this preprint (which was not certified by peer review) is the author/funder, who has granted medRxiv a license to display the preprint in perpetuity. It is made available under a CC-BY-NC-ND 4.0 International license .

Table 3: All metabolites that met q-value $<0.2$ in at least 1 primary model analysis that adjusts for matching factors. M1 is the simple model (accounting for matching factors) and M2 is the adjusted model (adjusting for matching factors and breast cancer risk factors).

\begin{tabular}{|c|c|c|c|c|c|c|c|c|}
\hline \multirow{2}{*}{ Metabolite } & \multirow{2}{*}{$\begin{array}{c}\text { Mod } \\
\text { el }\end{array}$} & \multicolumn{2}{|c|}{ Logistic } & \multicolumn{2}{|c|}{ Lasso } & \multicolumn{2}{|c|}{ Elastic Net } & \multirow{2}{*}{$\begin{array}{c}\text { Random } \\
\text { Forest } \\
\text { Raw P- } \\
\text { value } \\
\end{array}$} \\
\hline & & $\begin{array}{l}\text { Odds } \\
\text { Ratio }\end{array}$ & $\begin{array}{l}\text { Raw P- } \\
\text { value }\end{array}$ & $\begin{array}{l}\text { Odds } \\
\text { Ratio }\end{array}$ & $\begin{array}{l}\text { Raw P. } \\
\text { value }\end{array}$ & $\begin{array}{l}\text { Odds } \\
\text { Ratio }\end{array}$ & $\begin{array}{l}\text { Raw P. } \\
\text { value }\end{array}$ & \\
\hline \multirow{2}{*}{ DMGV } & M1 & 0.84 & 9.23E-05 & 0.87 & 4.00E-02 & 0.90 & 5.60E-02 & $<0.01$ \\
\hline & M2 & 0.88 & 1.10E-02 & 0.89 & 6.80E-02 & 0.96 & $1.64 \mathrm{E}-01$ & $<0.01$ \\
\hline \multirow{2}{*}{$\begin{array}{l}\text { 2-aminohippuric } \\
\text { acid }\end{array}$} & M1 & 0.84 & $1.42 E-04$ & 0.93 & $2.24 \mathrm{E}-01$ & 0.94 & $2.48 \mathrm{E}-01$ & 0.02 \\
\hline & M2 & 0.85 & 7.72E-04 & 0.92 & $1.56 \mathrm{E}-01$ & 0.96 & $9.60 \mathrm{E}-02$ & 0.02 \\
\hline \multirow{2}{*}{ piperine } & M1 & 0.85 & 4.59E-04 & 0.80 & $0.00 \mathrm{E}+00$ & 0.85 & $0.00 \mathrm{E}+00$ & $<0.01$ \\
\hline & M2 & 0.84 & 2.79E-04 & 0.78 & $0.00 \mathrm{E}+00$ & 0.92 & $1.60 \mathrm{E}-02$ & $<0.01$ \\
\hline \multirow{2}{*}{ kynurenic acid } & M1 & 0.87 & 3.00E-03 & 0.87 & 2.80E-02 & 0.90 & 5.60E-02 & 0.1 \\
\hline & M2 & 0.86 & 2.92E-03 & 0.86 & $1.20 \mathrm{E}-02$ & 0.96 & 8.80E-02 & 0.11 \\
\hline \multirow{2}{*}{$\begin{array}{c}\mathrm{N} 2, \mathrm{~N} 2- \\
\text { dimethylguanosine }\end{array}$} & M1 & 0.88 & 8.47E-03 & 1.00 & $1.00 \mathrm{E}+00$ & 0.97 & 6.04E-01 & $<0.01$ \\
\hline & M2 & 0.91 & 6.01E-02 & 1.00 & 5.04E-01 & 0.98 & 3.04E-01 & 0.05 \\
\hline \multirow{2}{*}{$\begin{array}{l}\text { phenylacetylglutami } \\
\text { ne }\end{array}$} & M1 & 0.89 & 1.15E-02 & 0.88 & 2.80E-02 & 0.90 & 5.20E-02 & 0.13 \\
\hline & M2 & 0.90 & 2.13E-02 & 0.89 & 2.40E-02 & 0.96 & $9.20 \mathrm{E}-02$ & 0.19 \\
\hline \multirow{2}{*}{$\begin{array}{c}\text { C34:3 PC } \\
\text { plasmalogen }\end{array}$} & M1 & 1.13 & 7.64E-03 & 1.24 & 2.80E-02 & 1.09 & $1.28 \mathrm{E}-01$ & 0.01 \\
\hline & M2 & 1.09 & 7.44E-02 & 1.29 & 1.60E-02 & 1.03 & $1.64 \mathrm{E}-01$ & $<0.01$ \\
\hline \multirow{2}{*}{ C20:1 LPC } & M1 & 1.13 & 9.00E-03 & 1.08 & $2.44 \mathrm{E}-01$ & 1.06 & 3.80E-01 & 0.17 \\
\hline & M2 & 1.10 & 5.18E-02 & 1.14 & 6.00E-02 & 1.02 & $2.76 \mathrm{E}-01$ & 0.25 \\
\hline \multirow{2}{*}{$\begin{array}{c}\text { C40:7 PE } \\
\text { plasmalogen }\end{array}$} & M1 & 1.14 & 3.23E-03 & 1.25 & $0.00 \mathrm{E}+00$ & 1.11 & 6.80E-02 & 0.01 \\
\hline & M2 & 1.11 & 3.01E-02 & 1.29 & $0.00 \mathrm{E}+00$ & 1.03 & $1.28 \mathrm{E}-01$ & 0.04 \\
\hline \multirow{2}{*}{ asparagine } & M1 & 1.14 & $6.10 \mathrm{E}-03$ & 1.22 & 2.80E-02 & 1.13 & 3.20E-02 & 0.02 \\
\hline & M2 & 1.10 & 5.41E-02 & 1.18 & 4.40E-02 & 1.04 & $1.20 \mathrm{E}-01$ & 0.03 \\
\hline \multirow{2}{*}{ creatine } & M1 & 1.10 & 3.94E-02 & 1.27 & $0.00 \mathrm{E}+00$ & 1.16 & $1.20 \mathrm{E}-02$ & 0.06 \\
\hline & M2 & 1.13 & 1.51E-02 & 1.24 & $0.00 \mathrm{E}+00$ & 1.05 & $5.60 \mathrm{E}-02$ & 0.07 \\
\hline
\end{tabular}

*: Simple model: adjusts for matching factors including menopausal status at blood draw, time of blood draw, date/season of blood draw, luteal day at blood draw, fasting status at blood draw, menopausal status at diagnosis and race.

** Adjusted model: in addition to matching factors, this model adjusts for BMI at age 18, weight change between age 18 and time of blood draw, age at menarche, parity and age at first birth, family history of breast cancer, personal history of benign breast disease, physical activity, alcohol consumption, exogenous hormone use, breast feeding history. 
medRxiv preprint doi: https://doi.org/10.1101/2020.09.01.20185835; this version posted September 2, 2020. The copyright holder for this preprint (which was not certified by peer review) is the author/funder, who has granted medRxiv a license to display the preprint in perpetuity. It is made available under a CC-BY-NC-ND 4.0 International license .

\section{Discussion}

We conducted a large-scale study of 207 circulating amino acid and amino acid-related metabolites, and risk of breast cancer in a nested case-control study (1057 cases and 1057 matched controls) within NHSII, a cohort of predominantly premenopausal women. Higher levels of six metabolites, 2-aminohippuric acid, DMGV, kynurenic acid, N2, N2-dimethylguanosine, phenylacetyl glutamine and piperine, were associated with lower breast cancer risk while higher levels of asparagine, creatine and 3 lipids, C20:1 LPC, C34:3 PC plasmalogen, C40:7 PE plasmalogen, were associated with increased breast cancer risk. Inverse associations between 2aminohippuric acid, DMGV, kynurenic acid, phenylacetyl glutamine and piperine, and the positive association with C40:7 PE plasmalogen remained statistically significant after adjusting for established risk factors. Notably, associations between 2-aminohippuric acid, piperine and kynurenic acid remained significant even after multiple testing correction. Piperine, 2-aminohippuric acid and C40:7 PE plasmalogen were also selected in multivariable modeling approaches (Lasso, Elastic Net, and Random Forests). None of the metabolites showed heterogeneity by BMI, except DMGV. None of the metabolites showed heterogeneity by ER status, except asparagine.

Piperine is a polyphenol responsible for the pungency of black and long pepper and exhibits a wide range of properties: anti-diabetic, anti-inflammatory, immunomodulatory, reduction of insulin resistance, and enhanced drug bioavailability ${ }^{33-35}$. Piperine also inhibits tumorigenesis, tumor angiogenesis, cancer cell proliferation, cancer cell migration and invasion, and enhances apoptosis and autophagy ${ }^{36}$. Experimental and cell line studies identified anti-breast cancer specific mechanisms of action, including decreased matrix metalloproteinase 9 (MMP-9) and MMP-13 expression, induced apoptosis through activation of caspase-3 and inhibition of human epidermal growth factor receptor 2 (HER2) gene expression ${ }^{37}$. Synergetic effects of piperine and chemotherapy drugs (paclitaxel,doxorubicin), hormone therapy drugs (tamoxifen), radiotherapy, TRAIL- and nano-deliverybased therapy drugs (paclitaxel, rapamycine) were observed ${ }^{37}$. Notably, piperine inhibited growth and motility $^{38}$, and enhanced efficacy of TRAIL-based therapy ${ }^{39}$ in triple-negative breast cancer cells, the most aggressive breast cancer subtype. In a previous study of the associations of diet-related metabolites and breast 
medRxiv preprint doi: https://doi.org/10.1101/2020.09.01.20185835; this version posted September 2, 2020. The copyright holder for this preprint (which was not certified by peer review) is the author/funder, who has granted medRxiv a license to display the preprint in perpetuity. It is made available under a CC-BY-NC-ND 4.0 International license.

cancer risk within the Prostate, Lung, Colorectal and Ovarian (PLCO) Cancer screening trial (n=1242, 621 cases), piperine was found to be modestly correlated with liquor consumption (correlation=0.16) and similar to our study, inversely associated with breast cancer risk $\left(\mathrm{OR}\right.$ comparing $90^{\text {th }}$ versus $10^{\text {th }}$ percentile $=0.74(0.56-$ 0.99, $\mathrm{p}=0.045)$ ), after adjusting for BMI and other potential confounders ${ }^{23}$. Notably, PLCO women were postmenopausal at the time of blood collection suggesting that the association between piperine and breast cancer may be independent of menopausal status.

Dimethylguanadino valeric acid (DMGV), an organic keto acid, is the product of transamination of asymmetric dimethylarginine (ADMA), which inhibits nitric oxide signaling that is crucial to endothelial function-excess ADMA is associated with increased risk of cardiovascular disease ${ }^{40,41}$. Plasma DMGV is positively associated with incident coronary artery disease, cardiovascular mortality, nonalcoholic fatty acid liver disease, and type II diabetes $^{42,43}$. Circulating DMGV is directly correlated with resistance to the metabolic benefits of exercise ${ }^{44}$. Physical activity, consumption of vegetables and red wine are associated with lower circulating DMGV, while sugar-sweetened beverage consumption is associated with higher circulating DMGV ${ }^{43,45}$. DMGV was associated with lower breast cancer risk in our study. The association between DMGV and breast cancer risk has not been previously assessed in prospective cohort studies. However, this metabolite was correlated with liver fat in the offspring cohort of the Framingham Heart Study $\left(\beta=0.02,95 \% \text { CI: } 0.018-0.022, p<10^{-23}\right)^{27}$. In addition, in the same study, baseline DMGV levels were associated with higher risk of type 2 diabetes, with replication of this association in the Malmo Diet and Cancer study and the Jackson Heart Study ${ }^{27}$. Large prospective studies are required to validate the association between DMGV and breast cancer risk. If replicated, experimental studies will be needed to understand the complex relationship between DMGV, diet, physical activity, CVD, type II diabetes, and breast cancer. Of note is that this analysis was in predominantly premenopausal women, among whom adiposity is also inversely associated with risk of breast cancer for reasons that are still not fully understood ${ }^{46}$. 
medRxiv preprint doi: https://doi.org/10.1101/2020.09.01.20185835; this version posted September 2, 2020. The copyright holder for this preprint (which was not certified by peer review) is the author/funder, who has granted medRxiv a license to display the preprint in perpetuity.

It is made available under a CC-BY-NC-ND 4.0 International license .

Although the measurement platform used here was optimized to measure amino acids and related metabolites, not lipids, our analysis included a small number of lipids and identified a few significant associations.

Plasmalogens are a subclass of phospholipids (components of the cell membrane and involved in cell signaling and cell cycle regulation ${ }^{47}$ ) that constitute $15-20 \%$ of all phospholipids in cell membranes ${ }^{48}$. Plasmalogens have head groups that are usually either phosphatidylcholine (PC plasmalogens) or ethanolamine (PE plasmalogens), and are characterized by an ether bond to an alkenyl group in the sn-1 position while the sn- 2 position is usually occupied by polyunsaturated fatty acids ${ }^{48}$. Certain cancers exhibit altered plasmalogen levels: circulating plasmalogens are depressed in pancreatic cancer patients ${ }^{49}$ and increased in gastric carcinoma patients ${ }^{50}$ compared to healthy controls. Our study identified two plasmalogens, C34:3 PC plasmalogen and C40:7 PE plasmalogen, associated with increased risk of breast cancer. The fatty acid component of specific lipids may also reflect dietary or metabolic processes; notably C40:7 PE plasmalogen is highly unsaturated but the position of the double bonds cannot be determined in this metabolomics assay. Among 74 women with breast cancer, the levels of the majority of measured phospholipids (LPC, LPE, PC and PE) were higher in tumor tissue when compared to normal breast tissue samples ${ }^{47}$. Similar trends were observed in another study comparing tumor to normal tissue in 257 participants with breast cancer, and these lipids were correlated with cancer progression and patient survival ${ }^{51}$. Contrary to our findings, in the European Prospective Investigation into Cancer (EPIC) cohort, PC plasmalogens, including C34:3 PC plasmalogen, were inversely associated with risk of breast cancer $^{18,19}$. However, neither study stratified their results by menopausal status, thus making a direct comparison difficult. Additional studies are needed to evaluate how plasmalogens are associated with risk of breast cancer and if this relationship is modulated by menopausal status.

LPCs are derived from phosphatidylcholines after hydrolysis of one of the fatty acid groups. In the liver, LPCs upregulate genes involved in cholesterol biosynthesis, while circulating LPCs activate many inflammatory and oxidative stress signaling pathways, and are associated with inflammatory diseases such as atherosclerosis and multiple sclerosis ${ }^{52}$. Circulating LPCs have mixed associations with certain cancers. For instance, circulating LPCs are elevated in ovarian cancer patients but depressed in leukemia patients relative to healthy controls ${ }^{53}$; 
medRxiv preprint doi: https://doi.org/10.1101/2020.09.01.20185835; this version posted September 2, 2020. The copyright holder for this preprint (which was not certified by peer review) is the author/funder, who has granted medRxiv a license to display the preprint in perpetuity.

It is made available under a CC-BY-NC-ND 4.0 International license .

LPCs showed inverse associations with risk of endometrioid and clear cell ovarian tumors, with stronger inverse associations among premenopausal women, in NHS and NHSII ${ }^{15,16}$. While most LPCs measured in EPIC were inversely associated with risk, one of our top hits was LPC C20:1 that was positively associated with risk ${ }^{18}$. In an earlier study nested within the EPIC cohort of 774 participants including 362 breast cancer cases, C18:0 LPC was identified as inversely associated with breast cancer risk, after adjusting for potential risk factors ${ }^{19}$, though analyses were not stratified by menopausal status.

Our study identified three amino acid derivatives associated with breast cancer risk. High levels of phenylacetylglutamine were associated with decreased breast cancer risk while high levels of asparagine and creatine were associated with increased risk. Phenylacetylglutamine is formed from phenylacetate and glutamine and is found as a normal constituent of human urine ${ }^{54}$. Phenylacetylglutamine is a host microbiome cometabolite associated with bacterial phenylalanine metabolism ${ }^{55-58}$. Clostridium difficile, F. prausnitzii, Bifidobacterium, Subdoligranulum, and Lactobacillus are all positively associated with hippuric acid ${ }^{57,59}$, while Bifidobacterium is positively associated with phenylacetylglutamine and microbes of the Christensellaceae, Ruminococcaceae, and Lachnospiracaea families are negatively associated with phenylacetylglutamine e $^{56,60}$. While not directly linked to breast cancer risk, high serum levels of phenylacetylglutamine is a potential early marker of kidney dysfunction in chronic kidney disease ${ }^{60}$. Glutamine, a precursor to phenylacetylglutamine, has been associated with breast cancer risk in a nested case-control study within the French Su.Vi.Max cohort ( $n=211$ cases). High levels of glutamine were associated with increased risk (OR per SD increase $=1.33,95 \%$ CI: 1.07-1.66) and this association persisted among the subgroup of premenopausal women ( $\mathrm{p}$ for interaction $=$ $0.003)^{20}$. In a nested case-control study within the EPIC cohort $(\mathrm{n}=1624$ cases), asparagine was inversely associated with breast cancer risk $(\mathrm{OR}=0.87$ per SD increase, 95\% CI: $0.80-0.95, \mathrm{FDR} p=0.06)$, in contrast to the direction of association in our study ${ }^{18}$. However, the EPIC study participants were overwhelmingly $(>70 \%)$ postmenopausal at the time of blood collection, in contrast to our population with $80 \%$ premenopausal women. Differences in the menopausal status may partially explain the observed opposite directions of association between asparagine and breast cancer risk. 
medRxiv preprint doi: https://doi.org/10.1101/2020.09.01.20185835; this version posted September 2, 2020. The copyright holder for this preprint (which was not certified by peer review) is the author/funder, who has granted medRxiv a license to display the preprint in perpetuity.

It is made available under a CC-BY-NC-ND 4.0 International license .

Creatine is obtained from meat consumption and synthesized endogenously from arginine, glycine, and methionine. Most creatine is found in skeletal muscle, and a significant amount is also found in the brain. Omnivores obtain roughly $50 \%$ of their daily creatine from meat and $50 \%$ is biosynthesized, while vegetarians biosynthesize most of their creatine ${ }^{61}$ and have significantly lower muscular creatine levels than meat eaters ${ }^{62}$. Creatine is broken down to creatinine in a first-order reaction, the rate of which decreases with age and decreased muscle mass ${ }^{63}$. Creatine/creatinine metabolism plays an important role in energy metabolism in skeletal muscle tissue, and thus disturbances in this pathway are associated with many muscle diseases, whether as a cause or consequence ${ }^{64}$. To the best of our knowledge, no previous work has reported a link between creatine and breast cancer risk. However, the association we observed in this analysis is consistent with the positive association between red meat and risk of breast cancer among premenopausal women in the NHSII cohort $^{65}$.

Kynurenic acid and 2-aminohippuric acid are benzenoids inversely associated with breast cancer risk in our study. 2-amminohippuric acid is a glycine conjugate of anthranilic acid and can be synthesized in the liver ${ }^{66}$, but little is known about its biological function. Both kynurenic acid and 2-aminohippuric acid are part of the kynurenine branch of the tryptophan pathway, an essential amino acid and a precursor to many biologically active metabolites $^{67,68}$. Studies of the function of kynurenic acid suggest pleiotropic roles in disease. On the one hand, kynurenic acid has been shown to have anti-inflammatory and anti-ulcerative properties in animal models, as well as antioxidative properties in vitro in human cells ${ }^{69}$. On the other hand, circulating kynurenic acid was associated with increased risk of insulin resistance ${ }^{70}$. Kynurenic acid acts as both an anti-inflammatory and immunosuppressive factor which in turn allows tumor proliferation ${ }^{71}$. Tryptophan metabolism plays an important role in tumor progression and malignancy with several cancers expressing tryptophan-degrading enzymes such as IDO1 ${ }^{72,73}$. However, the direct role of kynurenic acid remains unclear, with both proliferative and antiproliferative effects on human glioblastoma cells, an antiproliferative effect on human colon 
medRxiv preprint doi: https://doi.org/10.1101/2020.09.01.20185835; this version posted September 2, 2020. The copyright holder for this preprint (which was not certified by peer review) is the author/funder, who has granted medRxiv a license to display the preprint in perpetuity. It is made available under a CC-BY-NC-ND 4.0 International license .

adenocarcinoma cells, and decreased DNA synthesis and inhibited migration in both cell types ${ }^{69}$. Neither kynurenic acid nor 2-aminohippuric acid have been previously associated with breast cancer risk.

N2,N2-dimethylguanosine (DMGU) is a purine nucleoside and a primary degradation product of transport RNA. Elevated circulating DMGU levels may indicate cellular stress and is associated with several diseases, including pulmonary arterial hypertension ${ }^{74}$, solid tumors ${ }^{75}$, incident type II diabetes ${ }^{76}$, and all-cause mortality ${ }^{77}$. Elevated levels of N2, N2-dimethylguanosine were found in patients with acute leukemia and breast cancer $^{78}$. Elevated circulating levels of this metabolite are associated with lower risk of breast cancer in our study.

Our study has several strengths and limitations. Notably, we conducted a prospective analysis of amino acid and amino acid-related metabolomics and risk of breast cancer among a large number of predominantly premenopausal women. We had detailed information on sample collection characteristics and risk factors which we included in our statistical approaches. Although metabolomics was measured at only one point in time, the identified metabolites are reasonably stable over time ${ }^{29}$ (ICCs or correlation over 1-2 years $\geq 0.75$ for 9 metabolites; no data are available for 2-aminohippuric acid and C20:1 LPC). Our cohort consisted of registered nurses, a group that are not representative of the general population (e.g. social economic status), however there is no evidence suggesting that breast carcinogenesis is different in this group of women. While we had reasonable power in most of our analyses, we had limited power among ER negative tumors. Lastly, the uniqueness of our data measured among predominantly premenopausal women make replication studies challenging. We conducted this analysis in a hypothesis generating framework and hope that other cohorts will follow and analyze metabolomics data stratifying by menopausal status.

In summary, we identified several metabolites associated with risk of breast cancer among premenopausal women. Increased circulating levels of piperine, 2-aminohippuric acid and kynurenic acid are associated with lower risk of breast cancer, independent of established risk factors and after accounting for testing multiple hypotheses. Additional prospective cohort studies are needed to assess these associations considering 
medRxiv preprint doi: https://doi.org/10.1101/2020.09.01.20185835; this version posted September 2, 2020. The copyright holder for this preprint (which was not certified by peer review) is the author/funder, who has granted medRxiv a license to display the preprint in perpetuity. It is made available under a CC-BY-NC-ND 4.0 International license .

menopausal status. If these findings are validated, experimental studies are warranted to understand the

underlying biological mechanisms driving changes in metabolite levels.

\section{Acknowledgements}

This study was funded by the National Cancer Institute (R01 CA050385, UM1 CA186107, P01 CA087969,

R01 CA49449, U01 CA176726, R01 CA67262). We would like to thank the participants and staff of the

Nurses' Health Studies for their valuable contributions as well as the following state cancer registries for their

help: AL, AZ, AR, CA, CO, CT, DE, FL, GA, ID, IL, IN, IA, KY, LA, ME, MD, MA, MI, NE, NH, NJ, NY,

NC, ND, OH, OK, OR, PA, RI, SC, TN, TX, VA, WA, WY. The authors assume full responsibility for analyses and interpretation of these data.

\section{References}

1. Harbeck, N., et al. Breast cancer. Nature Reviews Disease Primers 5, 1-31 (2019).

2. Dartois, L., et al. Proportion of premenopausal and postmenopausal breast cancers attributable to known risk factors: Estimates from the E3N-EPIC cohort. International Journal of Cancer 138, 24152427 (2016).

3. Sprague, B.L., et al. Proportion of Invasive Breast Cancer Attributable to Risk Factors Modifiable after Menopause. American Journal of Epidemiology 168, 404-411 (2008).

4. Tamimi, R., et al. Population Attributable Risk of Modifiable and Nonmodifiable Breast Cancer Risk Factors in Postmenopausal Breast Cancer. American Journal of Epidemiology 184, 884-893 (2016).

5. Maas, P., et al. Breast Cancer Risk From Modifiable and Nonmodifiable Risk Factors Among White Women in the United States. Jama Oncology 2, 1295-1302 (2016).

6. Armitage, E.G. \& Barbas, C. Metabolomics in cancer biomarker discovery: Current trends and future perspectives. Journal of Pharmaceutical and Biomedical Analysis 87, 1-11 (2014).

7. McCartney, A., et al. Metabolomics in breast cancer: A decade in review. Cancer Treatment Reviews 67, 88-96 (2018).

8. Jiao, L., et al. A Prospective Targeted Serum Metabolomics Study of Pancreatic Cancer in Postmenopausal Women. Cancer Prev Res (Phila) 12, 237-246 (2019).

9. Mayers, J.R., et al. Elevation of circulating branched-chain amino acids is an early event in human pancreatic adenocarcinoma development. Nature medicine 20, 1193 (2014).

10. Shu, X., et al. Prospective metabolomics study identifies potential novel blood metabolites associated with pancreatic cancer risk. International Journal of Cancer 143, 2161-2167 (2018).

11. Huang, J., et al. Prospective serum metabolomic profiling of lethal prostate cancer. International Journal of Cancer 145, 3231-3243 (2019).

12. Wang, Y., Jacobs, E.J., Carter, B.D., Gapstur, S.M. \& Stevens, V.L. Plasma Metabolomic Profiles and Risk of Advanced and Fatal Prostate Cancer. Eur Urol Oncol (2019).

13. Loftfield, E., et al. Prospective investigation of serum metabolites, coffee drinking, liver cancer incidence, and liver disease mortality. J. Natl. Cancer Inst. (2019).

14. Perttula, K., et al. Untargeted lipidomic features associated with colorectal cancer in a prospective cohort. BMC Cancer 18, 996 (2018). 
medRxiv preprint doi: https://doi.org/10.1101/2020.09.01.20185835; this version posted September 2, 2020. The copyright holder for this preprint (which was not certified by peer review) is the author/funder, who has granted medRxiv a license to display the preprint in perpetuity. It is made available under a CC-BY-NC-ND 4.0 International license .

15. Zeleznik, O.A., et al. Circulating Lysophosphatidylcholines, Phosphatidylcholines, Ceramides, and Sphingomyelins and Ovarian Cancer Risk: A 23-Year Prospective Study. J Natl Cancer Inst (2019).

16. Zeleznik, O.A., et al. A prospective analysis of circulating plasma metabolites associated with ovarian cancer risk. Cancer Res. (2020).

17. Troisi, J., et al. Metabolomic Signature of Endometrial Cancer. J. Proteome Res. 17, 804-812 (2018).

18. His, M., et al. Prospective analysis of circulating metabolites and breast cancer in EPIC. BMC Medicine 17, 178 (2019).

19. Kühn, T., et al. Higher plasma levels of lysophosphatidylcholine 18:0 are related to a lower risk of common cancers in a prospective metabolomics study. BMC Medicine 14, 13 (2016).

20. Lécuyer, L., et al. Diet-related metabolomic signature of long-term breast cancer risk using penalized regression: an exploratory study in the SU.VI.MAX cohort. Cancer Epidemiol. Biomarkers Prev. (2019).

21. Moore, S.C., et al. A Metabolomics Analysis of Body Mass Index and Postmenopausal Breast Cancer Risk. J Natl Cancer Inst 110, 588-597 (2018).

22. Yoo, H.J., et al. Analysis of metabolites and metabolic pathways in breast cancer in a Korean prospective cohort: the Korean Cancer Prevention Study-II. Metabolomics 14, 85 (2018).

23. Playdon, M.C., et al. Nutritional metabolomics and breast cancer risk in a prospective study. Am J Clin Nutr 106, 637-649 (2017).

24. Eliassen, A.H., et al. Endogenous steroid hormone concentrations and risk of breast cancer among premenopausal women. J. Natl. Cancer Inst. 98, 1406-1415 (2006).

25. Fortner, R.T., et al. Parity, breastfeeding, and breast cancer risk by hormone receptor status and molecular phenotype: results from the Nurses' Health Studies. Breast Cancer Res. 21, 40 (2019).

26. Mascanfroni, I.D., et al. Metabolic control of type 1 regulatory T cell differentiation by AHR and HIF1- $\alpha$. Nature medicine 21, 638 (2015).

27. O'Sullivan, J.F., et al. Dimethylguanidino valeric acid is a marker of liver fat and predicts diabetes. The Journal of clinical investigation 127, 4394-4402 (2017).

28. Paynter, N.P., et al. Metabolic predictors of incident coronary heart disease in women. Circulation 137, 841-853 (2018).

29. Townsend, M.K., et al. Reproducibility of metabolomic profiles among men and women in 2 large cohort studies. Clinical chemistry 59, 1657-1667 (2013).

30. Avalos, M., Pouyes, H., Grandvalet, Y., Orriols, L. \& Lagarde, E. Sparse conditional logistic regression for analyzing large-scale matched data from epidemiological studies: a simple algorithm. BMC Bioinformatics 16, S1 (2015).

31. Breiman, L. Random forests. Machine learning 45, 5-32 (2001).

32. Storey, J.D. The positive false discovery rate: a Bayesian interpretation and the q-value. The Annals of Statistics 31, 2013-2035 (2003).

33. Derosa, G., Maffioli, P. \& Sahebkar, A. Piperine and its role in chronic diseases. in Anti-inflammatory Nutraceuticals and Chronic Diseases 173-184 (Springer, 2016).

34. Meghwal, M. \& Goswami, T. Piper nigrum and piperine: an update. Phytother. Res. 27, 1121-1130 (2013).

35. Yadav, V., Krishnan, A. \& Vohora, D. A systematic review on Piper longum L.: Bridging traditional knowledge and pharmacological evidence for future translational research. J. Ethnopharmacol., 112255 (2019).

36. Zadorozhna, M., Tataranni, T. \& Mangieri, D. Piperine: role in prevention and progression of cancer. Mol. Biol. Rep., 1-13 (2019).

37. Aumeeruddy, M.Z. \& Mahomoodally, M.F. Combating breast cancer using combination therapy with 3 phytochemicals: Piperine, sulforaphane, and thymoquinone. Cancer 125, 1600-1611 (2019).

38. Greenshields, A.L., et al. Piperine inhibits the growth and motility of triple-negative breast cancer cells. Cancer Lett. 357, 129-140 (2015).

39. Abdelhamed, S., et al. Piperine enhances the efficacy of TRAIL-based therapy for triple-negative breast cancer cells. Anticancer Res. 34, 1893-1899 (2014).

40. Rodionov, R.N., Murry, D.J., Vaulman, S.F., Stevens, J.W. \& Lentz, S.R. Human Alanine-Glyoxylate Aminotransferase 2 Lowers Asymmetric Dimethylarginine and Protects from Inhibition of Nitric Oxide Production. J. Biol. Chem. 285, 5385-5391 (2010).

41. Willeit, P., et al. Asymmetric Dimethylarginine and Cardiovascular Risk: Systematic Review and MetaAnalysis of 22 Prospective Studies. Journal of the American Heart Association 4, e001833. 
medRxiv preprint doi: https://doi.org/10.1101/2020.09.01.20185835; this version posted September 2, 2020. The copyright holder for this preprint (which was not certified by peer review) is the author/funder, who has granted medRxiv a license to display the preprint in perpetuity. It is made available under a CC-BY-NC-ND 4.0 International license .

42. O'Sullivan, J.F., et al. Dimethylguanidino valeric acid is a marker of liver fat and predicts diabetes. The Journal of Clinical Investigation 127, 4394-4402 (2017).

43. Ottosson, F., et al. Dimethylguanidino Valerate: A Lifestyle-Related Metabolite Associated With Future Coronary Artery Disease and Cardiovascular Mortality. Journal of the American Heart Association 8, e012846 (2019).

44. Robbins, J.M., et al. Association of Dimethylguanidino Valeric Acid With Partial Resistance to Metabolic Health Benefits of Regular Exercise. JAMA Cardiol 4, 636-643 (2019).

45. Hernández-Alonso, P., et al. Plasma Metabolites Associated with Frequent Red Wine Consumption: A Metabolomics Approach within the PREDIMED Study. Molecular Nutrition \& Food Research 63, 1900140 (2019).

46. Schoemaker, M.J., et al. Association of body mass index and age with subsequent breast cancer risk in premenopausal women. JAMA oncology 4, e181771-e181771 (2018).

47. Yamashita, Y., et al. Differences in elongation of very long chain fatty acids and fatty acid metabolism between triple-negative and hormone receptor-positive breast cancer. BMC Cancer 17, 589 (2017).

48. Messias, M.C.F., Mecatti, G.C., Priolli, D.G. \& de Oliveira Carvalho, P. Plasmalogen lipids: functional mechanism and their involvement in gastrointestinal cancer. Lipids in Health and Disease 17, 41 (2018).

49. Ritchie, S.A., et al. Metabolic system alterations in pancreatic cancer patient serum: potential for early detection. BMC Cancer 13, 416 (2013).

50. Lv, J., Lv, C.-Q., Xu, L. \& Yang, H. Plasma Content Variation and Correlation of Plasmalogen and GIS, TC, and TPL in Gastric Carcinoma Patients: A Comparative Study. Med Sci Monit Basic Res 21, 157160 (2015).

51. Hilvo, M., et al. Novel theranostic opportunities offered by characterization of altered membrane lipid metabolism in breast cancer progression. Cancer Res. 71, 3236-3245 (2011).

52. Law, S.-H., et al. An Updated Review of Lysophosphatidylcholine Metabolism in Human Diseases. Int $J$ Mol Sci 20(2019).

53. Libert, D.M., Nowacki, A.S. \& Natowicz, M.R. Metabolomic analysis of obesity, metabolic syndrome, and type 2 diabetes: amino acid and acylcarnitine levels change along a spectrum of metabolic wellness. PeerJ 6(2018).

54. PubChem Database. Vol. Phenylacetylglutamine, CID=92258 (accessed: March 27, 2020) https://pubchem.ncbi.nlm.nih.gov/compound/Phenylacetylglutamine (National Center for Biotechnology Information).

55. Lees, H.J., Swann, J.R., Wilson, I.D., Nicholson, J.K. \& Holmes, E. Hippurate: The Natural History of a Mammalian-Microbial Cometabolite. J. Proteome Res. 12, 1527-1546 (2013).

56. Li, M., et al. Symbiotic gut microbes modulate human metabolic phenotypes. Proceedings of the National Academy of Sciences of the United States of America 105, 2117-2122 (2008).

57. Pallister, T., et al. Hippurate as a metabolomic marker of gut microbiome diversity: Modulation by diet and relationship to metabolic syndrome. Sci Rep 7(2017).

58. Wikoff, W.R., et al. Metabolomics analysis reveals large effects of gut microflora on mammalian blood metabolites. Proceedings of the national academy of sciences 106, 3698-3703 (2009).

59. Behr, C., et al. Gut microbiome-related metabolic changes in plasma of antibiotic-treated rats. Arch Toxicol 91, 3439-3454 (2017).

60. Barrios, C., et al. Gut-microbiota-metabolite axis in early renal function decline. PloS one 10(2015).

61. Riesberg, L.A., Weed, S.A., McDonald, T.L., Eckerson, J.M. \& Drescher, K.M. Beyond muscles: The untapped potential of creatine. International immunopharmacology 37, 31-42 (2016).

62. Delanghe, J., et al. Normal reference values for creatine, creatinine, and carnitine are lower in vegetarians. Clinical chemistry 35, 1802-1803 (1989).

63. Brosnan, J.T. \& Brosnan, M.E. Creatine metabolism and the urea cycle. Molecular Genetics and Metabolism 100, S49-S52 (2010).

64. Wyss, M. \& Kaddurah-Daouk, R. Creatine and Creatinine Metabolism. Physiological Reviews 80, 11071213 (2000).

65. Farvid, M.S., Cho, E., Chen, W.Y., Eliassen, A.H. \& Willett, W.C. Dietary protein sources in early adulthood and breast cancer incidence: prospective cohort study. Bmj 348, g3437 (2014).

66. Naito, J., Sasaki, E., Ohta, Y., Shinohara, R. \& Ishiguro, I. Anthranilic acid metabolism in the isolated perfused rat liver: detection and determination of anthranilic acid and its related substances using high- 
medRxiv preprint doi: https://doi.org/10.1101/2020.09.01.20185835; this version posted September 2, 2020. The copyright holder for this preprint (which was not certified by peer review) is the author/funder, who has granted medRxiv a license to display the preprint in perpetuity. It is made available under a CC-BY-NC-ND 4.0 International license .

performance liquid chromatography with electrochemical detection. Biochemical pharmacology 33, 3195-3200 (1984).

67. Badawy, A.A.B. Kynurenine Pathway of Tryptophan Metabolism: Regulatory and Functional Aspects. International Journal of Tryptophan Research (2017).

68. Richard, D.M., et al. L-Tryptophan: Basic Metabolic Functions, Behavioral Research and Therapeutic Indications. Int J Tryptophan Res 2, 45-60 (2009).

69. Walczak, K., Wnorowski, A., Turski, W.A. \& Plech, T. Kynurenic acid and cancer: facts and controversies. Cell. Mol. Life Sci. (2019).

70. Yu, E., et al. Association of Tryptophan Metabolites with Incident Type 2 Diabetes in the PREDIMED Trial: A Case-Cohort Study. Clinical Chemistry 64, 1211-1220 (2018).

71. Wirthgen, E., Hoeflich, A., Rebl, A. \& Günther, J. Kynurenic acid: the Janus-faced role of an immunomodulatory tryptophan metabolite and its link to pathological conditions. Frontiers in immunology 8, 1957 (2018).

72. Platten, M., Nollen, E.A.A., Röhrig, U.F., Fallarino, F. \& Opitz, C.A. Tryptophan metabolism as a common therapeutic target in cancer, neurodegeneration and beyond. Nat Rev Drug Discov 18, 379401 (2019).

73. Labadie, B.W., Bao, R. \& Luke, J.J. Reimagining IDO pathway inhibition in cancer immunotherapy via downstream focus on the Tryptophan-Kynurenine-Aryl hydrocarbon axis. Clinical Cancer Research 25, 1462-1471 (2019).

74. Rhodes, C.J., et al. Plasma Metabolomics Implicates Modified Transfer RNAs and Altered Bioenergetics in the Outcomes of Pulmonary Arterial Hypertension. Circulation 135, 460-475 (2017).

75. Seidel, A., Brunner, S., Seidel, P., Fritz, G.I. \& Herbarth, O. Modified nucleosides: an accurate tumour marker for clinical diagnosis of cancer, early detection and therapy control. Br J Cancer 94, 1726-1733 (2006).

76. Ottosson, F., Smith, E., Gallo, W., Fernandez, C. \& Melander, O. Purine Metabolites and Carnitine Biosynthesis Intermediates Are Biomarkers for Incident Type 2 Diabetes. J. Clin. Endocrinol. Metab. 104, 4921-4930 (2019).

77. Balasubramanian, R., et al. Metabolomic profiles associated with all-cause mortality in the Women's Health Initiative. International Journal of Epidemiology, dyz211 (2019).

78. Levine, L., Waalkes, T.P. \& Stolbach, L. Brief Communication: Serum Levels of N 2, N 2Dimethylguanosine and Pseudouridine as Determined by Radioimmunoassay for Patients With Malignancy. J. Natl. Cancer Inst. 54, 341-343 (1975). 